\title{
Travels with Sally
}

\author{
D.C.F. Rentz
}

Since this is a book about the life of an anthropologist, one might ask how the modes of an entomologist are relevant. Sally White was married to M.J.D. (Michael) White who was first a geneticist and secondly an entomologist. Michael used 'orthopteroid' insects (grasshoppers, crickets, katydids, stick insects, mantids and the like) as his primary subjects. These insects are also my specialty. I study their systematics, that is, their classification, biology and behaviour. Geneticists have spent a lot of time looking at the chromosomes of these insects because they are abundant, large and relatively easily collected. The chromosomes are also relatively very large and this was very important in the early days before the tremendous advances in microscopy that we know today. Michael was one of the world's outstanding cytologists and made many important contributions during his productive life.

I joined CSIRO in 1976, after emigrating from my native California. I already knew Michael as a result of our mutual interests. Within a day of my arrival Michael and Sally offered greetings and the loan of basic necessities of life - a toaster and an electric 'jug'. The latter was a new item not previously encountered in California living. Water there is boiled on the stove! Several dinners were enjoyed at the White residence on Blackbutt Street (and Michael would repeat the word, stressing the 'butt' in his very characteristic vocal manner with darting eyebrows watching to see if a grin could be elicited). Fortunately (or unfortunately) he found me a ready audience for his many 'stories'. He reminded me somewhat of my grandfather. Sally knew all the stories and helped fill in the gaps. 'Tell him about the day Ken (Key) was chased by eagles...'she would say.

Within 6 weeks of my settling in Canberra, Michael offered me a field trip to south central Queensland. He was looking for certain kinds of morabine grasshoppers. These grasshoppers comprise about 250 species, all endemic to Australia. They are all slender, wingless creatures that look like matchsticks with legs. Michael's entomological colleague Ken Key (my predecessor) had been studying morabines for more than 30 years; he and Michael had written a number of joint papers (which Michael described as an exercise in 'entomological masochism'), and Michael needed to get more specimens from certain localities to confirm his hypotheses. [These papers are now considered classics in Australian entomological circles.] Sally told me that Michael was quite anxious to be the first to show me the Australian bush. She was preoccupied with other activities and so Michael and I set out visiting such places as Alpha, Jericho, Beta and even 'Whites Hole', all in Queensland. The first night we camped on the verge near Nyngan, New South Wales, and after dark (I do much collecting at night) I found some 
katydids called the Mountain Katydid in the adjacent 'paddock' (I was informed that they are not 'fields' here). I exclaimed that it didn't appear that there were any mountains for miles. Michael said that was correct and 'you can see why we need you here'.

Anyone who has camped with the Whites is soon to learn that they espouse no creature comforts. I was presented with a 'stretcher'. This is a canvas and wire gismo on which one reclines. Without any tuition (instruction in Yankese) my attempts to put the thing together must have become the basis for another 'Michael story'. I still despise those things. The remainder of the camping gear seemed quite primitive to my thinking. Cooking was done on a gas stove placed on the ground, which I thought was dangerous. The gas-jets seemed to always be clogged and when Sally was along a great deal of time was spent trying to clean them; an entire morning was occupied in the Longreach hardware store with Michael and the owner blowing compressed air through the system because there were no replacements.

\section{Way Out West}

Way Out West is one of my favourite Laurel and Hardy comedies and I thought appropriate for these tales. I took several trips with the Whites and my ex-wife Barbara to Western Australia. The ultimate destinations were localities in the vicinity of Kalgoorlie. The Diorite King Mine seems to stand out. Whilst in Kalgoorlie, they had to show me 'that street!' On each occasion when we travelled through Menzies I was informed that ex-President Herbert Hoover spent some time as a metallurgist there before becoming president of the USA. The routine of a field trip was not for everyone, but I found the companionship and humour to be well worth the discomfort. And the gems of information from both Sally and Michael I utilise to this day. Other participants in the White's field excursions will recall the 'card table' held together by countless screws

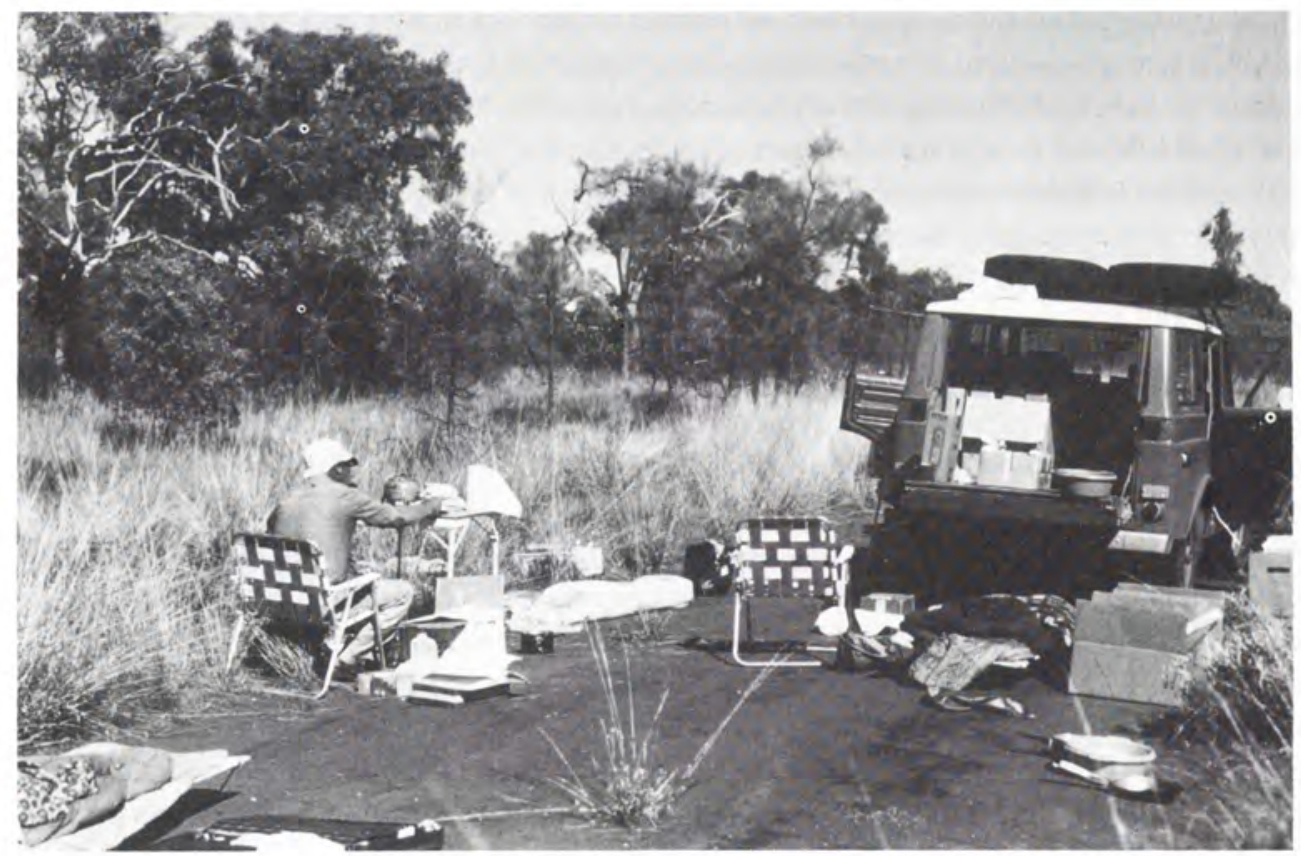

A White roadside camp between Nyngan, New South Wales and southern Queensland, October 1977. Michael prepares breakfast at the card table. 
that had to be tightened with each use, and the unique 'White Tent', surely the precursor for the Sydney Opera House.

One time Michael wanted to show me Fowlers Bay, not far from Ceduna, South Australia. It was blowing a gale. After some time we arrived in a full sandstorm. Of course, nothing was collected. In the morning, with the wind still blowing, I found Sally on her knees with the stove on the ground under the rear of the Toyota Landcruiser cooking bacon and eggs. She exclaimed that Michael was English, you know, and he had to have bacon and eggs every morning no matter what the conditions. I noticed a considerable lacing of sand with the food. She said it wouldn't worry Michael. I've returned to Fowlers Bay on several occasions since that visit and still don't see what they both felt was so special about the spot.

\section{Yalata connections}

Each trip out west had the perfunctory stop at Yalata where Sally would confer with certain women in the local aboriginal community. She was preparing her article for Fighters and singers, a book documenting the contributions of certain important women in a number of Aboriginal communities. I recall the efforts to find the respective women with whom she was conferring. We always located them - eventually. After a few inquiries we seemed to head off 'aimlessly' into the mulga for many many kilometres, often asking a question of passers-by as to the whereabouts of certain women. One time after more than an hour of driving we eventually came to the lady in question, seated upon a sofa under the wattles. After thinking about it, this was the coolest and most pleasant place to be on a hot February afternoon.

\section{Does it ever stop raining at Mt Ragged?}

Mt Ragged, Western Australia, is one of those remote localities that one finds on the labels of many insects in the Australian National Insect Collection in Canberra. While I was studying Australian insects when in the USA, I frequently wondered what the area was like. It had produced so many interesting katydids with more than $80 \%$ undescribed species. When the Whites decided that a trip down there for a couple of days was entirely possible, I was elated at the opportunity to see the place and look for katydids there. I have subsequently visited the place four times, each time punctuated by a disaster that required an early departure.

The first trip required travel south from Balladonia through the mixed woodland. Michael and Sally were intrigued by 'Balladonia time' which was some 15 minutes different from the time at localities on either side of the place. This reflects the remoteness of this community. We started the transect south towards Mt Ragged well after 3.00 p.m. Around 6.00 p.m. we decided to stop and set up camp. We found a pleasant spot among the Cratystylus and mallees on the edge of a dry lake. After the 'cocktail hour' and story-time and dinner, I set out on foot collecting in the general vicinity. I used the camp lights for bearings as getting lost is the greatest hazard in the Australian bush, not encounters with snakes, yowies and the like. Snooping around vegetation and bending over to look at creatures on the ground can leave one disoriented. At one point I looked around to find my beacon lights and, alas, none were to be seen. I moved a short distance in various directions and decided I was indeed 'bushed'. It was a dark night with no moon so there was not much ambient light. I tried calling: nothing; I used the police 


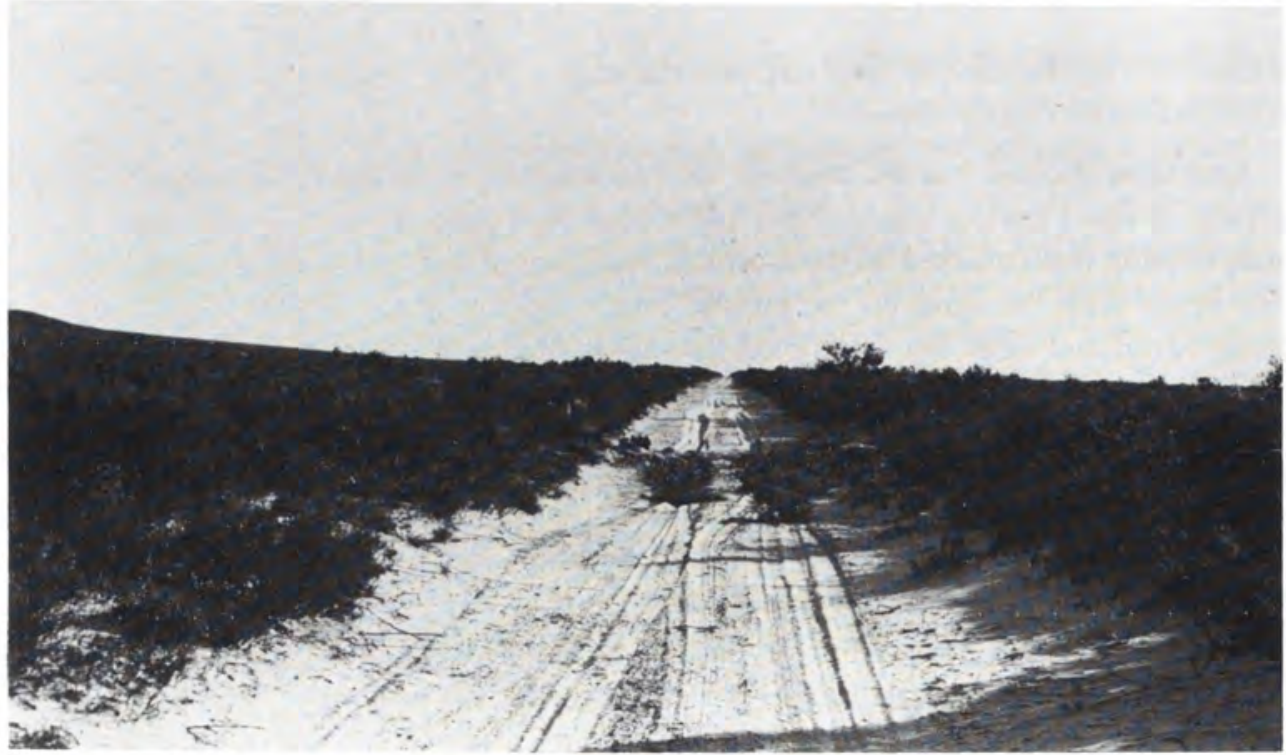

The Mt Raggea road atter heavy raın during one of the White-Rentz field trips.

whistle I was instructed to carry: nothing; I tried climbing a tree or two but they were all the same size and I couldn't see a thing. I had a hunch to walk in a line in a certain direction. This I did and eventually found the clearing and dry lake. I then knew where to find the camp. On arrival I awakened the sleeping Whites who said they retired and merely turned off the camp lights, not realising I was using them as a beacon. They said they heard some sorts of noise but thought it was only 'curlews'. On all subsequent nights, the camp light was placed atop the vehicle, 'or David would get lost.' I suspect after that occurrence I was the topic of yet another 'story'.

We arrived at Mt Ragged in mid-afternoon in sunshine and scattered thunderclouds, and I walked about the heath vegetation and discovered what a diverse and marvellous orthopteroid fauna lived there. At dinner we decided to spend $a b c-t$ three days there to really sample the grasshoppers. After a successful night's collecting I settled down in my 'stretcher' and a short time later a few raindrops were felt. Shortly it became more intense and the 'Opera House' was erected. It seemed to rain continuously, and about 4.00 a. m. Michael announced that we should probably leave at dawn since with such large amounts of water on the track he felt my VW Kombi van would not be able to make the trip south to the Esperance road. So there were no bacon and eggs in the morning, and we left at dawn going back to Balladonia. Michael was right, he had to tow me over a considerable distance through muddy puddles that would have delayed me for some days had I been on my own. The next trip a couple of years later resulted in the same fate only I ended up being towed in the opposite direction toward Esperance. The last trip to Mt Ragged was in February 1991, and was by far the most miserable. We had arrived in scorching heat and high winds. No tent could be secured. Sand was blowing everywhere and in the night lightning started a fire-storm in the west and by dawn's light the fire was approaching camp. We beat a hasty retreat later discovering that the fire had engulfed the camp, burning tables, toilets and, of course, all the interesting vegetation. 
For all the travail at Mt Ragged, I have made some wonderful entomological discoveries. I affectionately named White's Elusive Shield-backed Katydid Ixalodectes whitei Rentz from a locality not far from Mt Ragged, collected during a brief stop whilst I was being towed down the track. A species dedicated to Sally will appear in the next volume of my monograph series, volume 3, 'A Monograph of the Tettigoniidae of Australia'.

\section{The Musgrave Ranges}

The last trip I took with the Whites was to the Musgrave Ranges of central Australia in January 1982. The purposes of the trip were to try and map the geographical limits of a morabine grasshopper Michael was studying and for Sally to make contact with some folks at Amata. I went along because of the collecting opportunities offered in localities not usually accessible to entomologists. The weather was extreme - hot and dry. It was $52^{\circ} \mathrm{C}$ at Kulgera where we were told 'the frogs have forgotten how to swim.' We were completely knocked out by the heat - except for Sally. She didn't seem too worried by it. At one point when we were completely exhausted, Sally suggested we stop in a shady grove of she-oaks (Casuarina decaisneana) and take out the stretchers and just relax until nightfall. This we did, except for Sally who sat in a chair, read a book and sewed Michael's net. We eventually decided to spend a night in a motel and headed off to Kulgera where an eventful night was spent tending the evaporative cooler. It would have been more relaxing in the field. We never did find the exclusive morabine grasshopper and Michael reminded us that this negative evidence did not affect his hypothesis - it might be there only we missed it. And to add to the dismay, Sally did not meet the folks she wanted to see. It seems they had all gone off to Yalata!

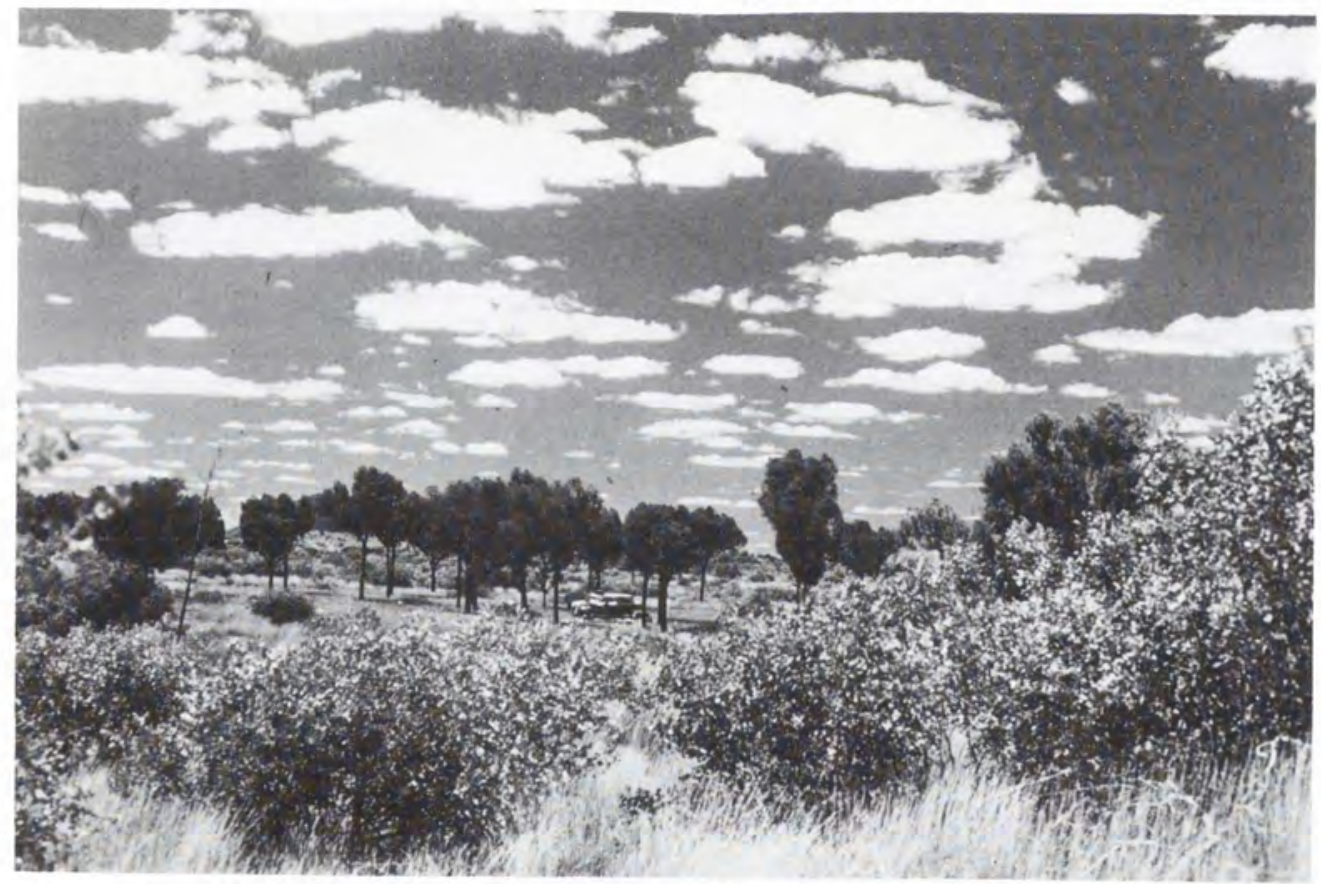

A White-Rentz camp, Musgrave Ranges, January 1982. 


\section{Summary}

Sally White always had an interesting way of looking at things. She could be relied upon to have an opinion completely different from what one might expect. I was puzzled why aboriginal women wore dresses in the desert. Wouldn't it be more practical to wear trousers? 'Oh, no', she said, 'It's a hangover from the Mission days. And anyways, it's more comfortable.' Sally herself usually wore a dress in the field, and she was not influenced by the missions.

Sally was a treasure and was recognised as such by her Aboriginal friends. I guess that's why they addressed her as 'grandmother'. I have told only a few stories: others escape me now, and still others just can't be repeated. I consider my time with the Whites as some of the most memorable experiences of my life and am privileged to have been able to relate some of them here.

David Rentz is an entomologist and scientific project leader with the Division of Entomology of the Commonwealth Scientific and Industrial Research Organisation in Canberra. 